\title{
Disaster Preparedness Analysis of Public Health Centers in DKI Jakarta Province in 2020
}

Nobella Firdausi, Fatma Lestari*, Avinia Ismiyati

Department of Occupational Safety and Health, Faculty of Public Health, Universitas Indonesia, Depok 16424, Indonesia

Corresponding Author Email: fatma@ui.ac.id

https://doi.org/10.18280/ijsse.110110

Received: 31 December 2020

Accepted: 5 Feburary 2021

\section{Keywords:}

disaster preparedness, hospital safety index, emergency, public health center

\begin{abstract}
This study describes the disaster preparedness level of public health centers in DKI Jakarta Province to deal with disasters. The study for this mini-thesis used a mixed method approach. Data were collected through interviews, observations, and document reviews by referring to the guideline in the PAHO: Evaluation of small \& medium-sized health facilities series 4 . Variables studied were disaster potentials, structural safety, nonstructural safety, and functional aspects that were then synthesized to determine the disaster preparedness level of the public health center, which is referred to as Puskesmas in Indonesian. Results showed that the preparedness scores were 0.65 and 0.6 for Puskesmas X and Puskesmas Y, respectively. This means that both public health centers are in the preparedness level $\mathrm{B}$, requiring both public health centers to do interventions in the near future because they still have risks when facing disasters. The score for structural safety of both public health centers was 0.77 , or classified as "a". This reflects the adequacy of the structural safety of both public health centers to face disasters. The nonstructural safety scores for Puskesmas X and Puskesmas $\mathrm{Y}$ were 0.65 and 0.63, respectively, which were interpreted as "b" classification. This shows that both public health centers still have risks in terms of their non-structural aspect when dealing with disasters. The scores for the functional aspect of Puskesmas $\mathrm{X}$ was 0.53 , while Puskesmas $\mathrm{Y}$ presented a score of 0.39 . Hence, the functional aspect of the two public health centers was in "b" classification, meaning that both public health centers still have risks in terms of their functional aspect when dealing with disasters. Therefore, both public health centers must continue to improve the disaster preparedness level of their facilities in terms of their structural, non-structural, and functional safety aspects.
\end{abstract}

\section{INTRODUCTION}

Geologically, Indonesia is located on a seismically active junction between three main tectonic plates and one small tectonic plate. This location makes this country experience frequent earthquakes and tsunamis that are triggered by earthquakes under the sea $[1,2]$. Indonesia is also prone to volcanic eruptions due to the high number of volcanoes in the country. Indonesia has 127 active volcanoes out of 500 existing volcanoes [3].

Geographically, Indonesia has a tropical climate with two seasons: the rainy season and the dry season. The climate is characterized by quite extreme changes in temperature, weather, and wind direction. This condition, along with environmental damage, may trigger hydrometeorological disasters such as floods, droughts, forest fires, and landslides [2]. Other potential disasters in Indonesia include disease outbreaks, technological failures, and social conflicts. The social conflicts that may arise in this country link to the fact that this country has diverse religions, ethnic groups, and customs. Rapid population growth and inequalities in terms of development policies, economic development, social development, and infrastructures can create gaps and also social jealousy $[2,4]$.

According to UN-ISDR, Indonesia is one of the countries with the highest risks for disasters in the world based on the number of people who will lose their lives in the case of a disaster [2]. Between 2015 and 2019, 10,956 disasters have occurred in Indonesia. The three most frequent disasters during that period are tornadoes, floods, and landslides. Other disasters have also occurred, including forest and land fires, drought, earthquakes, abrasion, volcanic eruptions, transportation accidents, collapsed bridges, fires, tsunamis, floods and landslides, social unrest, and acts of terror [5]. In 2020, Indonesia also hits by a pandemic, COVID-19 pandemic. As of July 28, 2020, there are 102,051 COVID-19 confirmed cases, with 58,173 patients have recovered and 4,838 patients died [6].

The abovementioned disasters will certainly affect health facilities due to, among others, damaged buildings, reduced personnel, impact on the population (injuries and diseases), disruption of primary health care services, and disruption of normal life [7]. Evidenced by the earthquake and tsunami in Palu in 2018, the disaster has damaged many health facilities, including the Anutapura Hospital, where the building collapsed and split into two [8]. COVID-19 also brings a grave impact on health services. According to the Ministry of Health Director of Health Surveillance and Quarantine, 83.9\% of health services throughout Indonesia were affected by the COVID-19 pandemic. One of the impacts is the cessation of the immunization program [9].

Health facilities play an important role during disasters in saving lives and providing care to the affected population. Health facilities must be able to survive and continue to 
function during and after a disaster [10]. A previous study on ten (10) hospitals in West Java and five (5) hospitals in Yogyakarta showed that the average preparedness level of these hospitals is B, meaning that there is still a risk regarding whether the hospital will be able to function during and after a disaster and that interventions are required in the near future [11].

Pursuant to the Regulation of the Minister of Health of the Republic Indonesia number 43 in 2019, the health care facility at the forefront for organizing public health efforts (PHEs) and individual health efforts (IHEs) is the Public Health Centers. The public health centers, or referred to as Puskesmas in Indonesian, still has to perform its duties and functions as the primary level health facility during a disaster and continues to empower the community and becomes the motor for public health development [12]. Because the public health center plays a crucial role during a disaster, efforts are needed to improve its disaster preparedness so it can save lives and provide health services to the community [13].

Based on the disaster risk mapping analysis of DKI Jakarta Province, potential disasters in DKI Jakarta include floods, fires, epidemics, social conflicts, technological failures, tornadoes, landslides, earthquakes, and tidal waves [14]. These disasters will certainly affect the function of Puskesmas, as evidenced by the situation caused by the floods in 2014, 2017, and 2018. At that time, the floods damaged Puskesmas Bidara Cina, a public health center located near the Ciliwung riverbank, and paralyzed the health services because the building was immersed in approximately $1 \mathrm{~m}$ high flood [15]. Recently, several employees of the Subdistrict Puskesmas Kebun Jeruk and Subdistrict Puskesmas Cempaka Putih were confirmed to suffer from COVID-19, requiring a temporary transfer of health services to the urban village public health centers to prevent further spread of the pandemic $[16,17]$.

Disaster preparedness assessment of health facilities is very important because of various disaster had happened in the past and that the preparedness level of health facilitiesis very significant in dealing with disaster [10]. Therefore, this study aimed to identify the disaster preparedness level of public health centers in DKI Jakarta Province to deal with disasters.

\section{LITERATURE REVIEW}

Safe hospital is a health facility where the services can still be accessed and functioned before, during, and immediately after a disaster. The purpose of this safe hospital is to ensure that health facilities remain intact in the event of a disaster and function effectively and without interferences [18]. In a study conducted by Mulyasari et al. in 2013 stated that assessing disaster preparedness in health facilities which are classified as critical facilities is very essential to do. It is because health facilities have a role in disaster recovery socially, economically and psychologically. In this study, although the survey response rate in the study conducted using Hospital Safety Index by Mulyasari et al. was classified as low, the results of study could provide an initial assessment of hospital disaster preparedness from several important earthquakeprone areas in Japan and identify preparedness and implement the facilities of this area. The results of this study can be used as a starting point for building further hospital resilience to future risks [10].

The Hospital Safety Index (HSI) is a tool used to measure the overall safety level of a hospital or health facility in an emergency. To assess small and medium health facilities such as a Public Health Center, the HSI also provides an assessment tool that has been adapted for health facilities of medium and small complexities [19]. This tool provides information on how to identify vulnerabilities in the structural, nonstructural, and functional aspects of a health facility. The results of the assessment can serve as a guide for interventions to improve the safety of a facility from natural hazards and other hazards. The tool consists of four modules [20]:

\subsection{Module 1 (Potential disaster)}

This module describes issues related to the geographic location of the public health center to help identify hazards in the facility. The potential for disasters varies between public health centers depending on where the public health center is located. To determine the disaster risk of a public health center, a review on area risk map, wind map, geological map, history of previous events, information about the community served, and observation on the environment inside and around the public health center is needed. The types of potential disasters that can occur in a public health center include geological, hydro-meteorological, social, environmental health, technology, and geotechnical disasters [20].

\subsection{Module 2 (Structural safety)}

Structural elements are defined as the building elements that bear loads and support the building structures so that the building remains intact. These include foundations, columns, beams, walls, roof frames, and others [21]. Failure in any of these structural elements can cause serious problems, such as the collapse of the building. The structural safety of the building is influenced by the history of the public health center building, the structural design, and the types of materials used for the building [20].

\subsection{Module 3 (Nonstructural safety)}

Nonstructural elements are anything that is in or on a building but is not a part of a structural element or a loadbearing part. Failure of this element will not destroy buildings [21]. However, it can endanger lives and interfere with the welfare of people in the public health center. Nonstructural elements include critical (lifeline) systems (electrical system, telecommunications system, water supply systems, fuel storage, medical gases, sanitation system, and water drainage systems), HVAC system, furniture, office equipment, laboratory equipment, medical equipment, and architectural components [20].

\subsection{Module 4 (Functional aspects)}

Public health center plays an important role in providing health care in an effective, efficient, and timely manner. The public health center must prepare their functional capacity to be able to respond to disaster events. There are cases where the health care facilities stop functioning even though the structures and other building elements are not affected. This is due to the functional collapse caused by the saturation of services triggered by inadequate disaster preparedness. The functional aspect discusses disaster committee, disaster response plan, and the availability of medicines, supplies, instruments, and equipment for disaster situations so that the 
public health center can continue to function [20].

During the COVID-19 pandemic, public health centers played an important role in preventing, detecting, and responding to COVID-19 cases in the effort to control the number of cases. As a guideline on providing services during a pandemic for public health centers, the Technical Guideline for public health center services during the COVID-19 Pandemic has been issued by the Indonesian Ministry of Health to be used as a reference for public health centers. This guideline describes approaches for public health center management, PHE implementation, IHE implementation, and IPC (infection Prevention and Control) implementation during the COVID-19 pandemic [22].

\section{METHOD}

This study used a mixed method approach and was performed in Puskesmas X and Puskesmas Y in South Jakarta. Sampling was performed using the purposive sampling method as recommended by the DKI Jakarta Provincial Health Office. The two public health centers were selected because their locations were close to Depok area, making it possible to access both public health centers despite the implementation of the Large-Scale Social Restriction due to the pandemic. Staff members of Puskesmas X became the informants for this study are staff who was in charge of OSH and administration unit. The informants from puskesmas $\mathrm{Y}$ are staff from the environmental health, administration unit, and staff who was in charge of OSH.

Primary data were generated from interviews with informants using questionnaire guidelines from PAHO: Evaluation of small \& medium-sized health facilities series 4 and also from observations of puskesmas facilities and infrastructure such as electrical systems, water supply systems, building conditions, medical gas storage locations, and fire protection systems and also documents review. The detail instruments used consist of forms from PAHO: hospital safety index (HSI): medium and small series of hospital safety index 4 , which consist of potential disaster module, structural safety module, nonstructural safety module, and functional aspect module. Data were then analyzed using univariate analysis by presenting important information related to variables and performing classification of disaster preparedness to describe or explain the condition of the disaster preparedness in the public health center.

In each module, an evaluation and assessment result is obtained with a value of $0-1$, which 0 is the lowest and 1 is the highest. Based on the scores from the structural safety, nonstructural safety, and functional aspect modules were averaged and the average score of each module was added and divided by the number of modules. Based on the WHO guideline, the results of the module evaluation were then classified into three classifications: C (0-0.35), B (0.36-0.65), and A (0.66-1). Data triangulation was performed through interviews, observations, and document reviews to ensure the accuracy of data sources in this process.

\section{RESULTS}

Puskesmas $\mathrm{X}$ is one of the public health centers in South Jakarta that was built in 1975 and rebuilt in 2004. Puskesmas $\mathrm{X}$ oversees five urban village health centers (Puskesmas
Kelurahan) and has a capacity of 10 inpatient beds in the maternity unit. The total population in the sub-district under this public health center is 205,441 , consisting of 102,855 males and 102,586 women. Puskesmas Y was founded in 1995 and oversees nine urban village public health centers (Puskesmas Kelurahan). Puskesmas Y has a capacity of 10 inpatient beds in the maternity unit. The total population in the sub-district under this public health center is 309,274 , consisting of 153,442 males and 155,832 females. This study was performed by assessing the structural safety, nonstructural safety, and functional aspects. The followings are the results of the assessment.

\subsection{Structural safety}

The assessment of the public health center building structural safety was based on the history of the public health center, as well as the structural design and the type of materials used in the building. Based on PAHO guidelines, structural safety module consists of 2 submodules. First, degree of safety in relation to the history of hospital. In this submodule, there are 3 items that need to be assessed, they are prior major structural damage or failure of hospital building, hospital built and/or repaired using the current safety standards and effect of remodeling or modification on the structural behavior of the hospital. Second submodule of structural safety module is building integrity. The assessment items in building integrity are condition of the building, condition of construction materials, interaction of nonstructural elements with the structure, building proximity, structural redundancy, safety of foundations, irregularities in building structure plan (rigidity, mass, resistance), irregularities in elevation of buildings, structural integrity of roofs, and structural resilience to hazards other than earth- quakes and strong winds. Detailed results are presented in the following Table 1:

Table 1. Overall structural safety assessment

\begin{tabular}{cccc}
\hline No & Submodule & $\begin{array}{c}\text { Total Score of } \\
\text { Puskesmas X }\end{array}$ & $\begin{array}{c}\text { Total Score of } \\
\text { Puskesmas } \mathbf{Y}\end{array}$ \\
\hline $1 \quad$ & 1.5 & 1.5 \\
& $\begin{array}{c}\text { Degree of safety in } \\
\text { relation to the history } \\
\text { of the hospital }\end{array}$ & & \\
\hline 2 & Building Integrity & 8.5 & 8,5 \\
\hline Total Score & 10 & 10 \\
\hline $\begin{array}{c}\text { Structural Safety Module } \\
\text { Score }\end{array}$ & 0.77 & 0.77 \\
\hline
\end{tabular}

The calculation on the score for the structural safety of the two public health centers resulted in a 0.77 score, or "a" classification. This score means that the structural safety of Puskesmas $\mathrm{X}$ and $\mathrm{Y}$ buildings is adequate for facing disasters.

\subsection{Nonstructural safety}

Nonstructural safety module assesses the critical systems, HVAC systems, furniture, storage units, office equipment, medical equipment, laboratory equipment, and architectural elements of the public health center. Results of the nonstructural safety assessment of the public health centers are listed below (Table 2).

Puskesmas X received a score of 0.65 , while Puskesmas $\mathrm{Y}$ received a score of 0.63 . The scores for the two Puskesmas are in the "b" classification, which means that in terms of the 
nonstructural safety, these public health centers still carries risks for surviving a disaster situation.

Table 2. Nonstructural safety assessment

\begin{tabular}{|c|c|c|c|}
\hline No & Submodule & $\begin{array}{c}\text { Total Score } \\
\text { of } \\
\text { Puskesmas } \\
\text { X } \\
\end{array}$ & $\begin{array}{c}\text { Total Score } \\
\text { of } \\
\text { Puskesmas } \\
\text { Y } \\
\end{array}$ \\
\hline \multirow[t]{8}{*}{1} & Critical system & & \\
\hline & Electrical system & 4 & 2.5 \\
\hline & $\begin{array}{c}\text { Telecommunications } \\
\text { system }\end{array}$ & 2 & 2 \\
\hline & Water supply system & 4 & 3.5 \\
\hline & Fuel storage & 0 & 0.5 \\
\hline & Medical gas (oxygen) & 0.5 & 0.5 \\
\hline & Sanitation system & 2.5 & 2.5 \\
\hline & Drainage system & 0.5 & 1 \\
\hline 2 & HVAC system & 1.5 & 1,5 \\
\hline 3 & $\begin{array}{c}\text { Furniture and fittings, } \\
\text { office and storage } \\
\text { equipment }\end{array}$ & 2 & 2 \\
\hline 4 & $\begin{array}{l}\text { Medical and laboratory } \\
\text { equipment and supplies } \\
\text { used for diagnosis and } \\
\text { treatment }\end{array}$ & 1 & 1 \\
\hline \multirow[t]{2}{*}{5} & Architectural component & 12.5 & 12,5 \\
\hline & Total Score & 30.5 & 29.5 \\
\hline \multicolumn{2}{|c|}{$\begin{array}{l}\text { Nonstructural Safety Module } \\
\text { Score }\end{array}$} & 0.65 & 0.63 \\
\hline
\end{tabular}

\subsection{Functional aspects}

The functional aspects of the public health centers were assessed based on the availability of the public health center disaster committee and disaster response plan, as well as the availability of medicines, supplies, instruments, and equipment for disaster situations. The Table 3 below presents the results of the functional aspect assessment in the two public health centers.

Table 3. Functional aspect assessment

\begin{tabular}{cccc}
\hline No & Submodule & $\begin{array}{c}\text { Total Score } \\
\text { of Puskesmas } \\
\text { X }\end{array}$ & $\begin{array}{c}\text { Total Score } \\
\text { of Puskesmas } \\
\text { Y }\end{array}$ \\
\hline 1 & 2.5 & 1 \\
\hline $2 \quad \begin{array}{c}\text { Ddisaster committee } \\
\text { organization }\end{array}$ & $\begin{array}{c}\text { Emergency or disaster } \\
\text { response plan }\end{array}$ & 10.5 & 7 \\
\hline $3 \quad \begin{array}{c}\text { Availability of } \\
\text { medicines, supplies, } \\
\text { instruments, and } \\
\text { equipment for disaster } \\
\text { situation }\end{array}$ & 4.5 & 5 \\
\hline Total Score & 17.5 & 13 \\
\hline Functional Aspect Module \\
Score
\end{tabular}

The scores for the functional aspect for Puskesmas $\mathrm{X}$ and Puskesmas $\mathrm{Y}$ were 0.53 and 0.39 , respectively. These scores place the two public health centers in the " $b$ " classification, meaning that both public health centers still carry risks when dealing with disasters in this aspect.

\subsection{Public health center safety index}

The scores from each module were added, and the result was then divided by the number of modules to obtain the overall safety index score for the public health center

Public Health Center Safety Index Score = strucural safety score +nonstructural safety score + functional aspect score

$$
\begin{aligned}
& \text { Safety index score for Puskesmas } \mathrm{X}=\frac{0.77+0.65+0.53}{3}=0.65 \\
& \text { Safety index score for Puskesmas } \mathrm{Y}=\frac{0.77+0.63+0.39}{3}=0.6
\end{aligned}
$$

From the calculation using the above formula, it was revealed that the safety index score for Puskesmas $\mathrm{X}$ was 0.65 , while the score for Puskesmas Y was 0.6, which fell into the B classification. This shows that both Puskesmas X and Y still carried risks when dealing with disasters that interventions are needed in the near future.

\section{DISCUSSIONS}

\subsection{Potential disasters in public health centers}

Potential disasters in working areas of Puskesmas $X$ and Y are identified using a hazard list from the hospital safety index: medium and small hospital safety index series 4 . Based on the history of events that have occurred, map the risk of the area, information about the communities served, and review environment in the area, main potential disasters at Puskesmas $\mathrm{X}$ and $\mathrm{Y}$ are earthquakes, landslides, tornadoes, floods, overflowing rivers, population concentration, social conflicts, disease outbreaks, water pollution, animal attacks, poisoning, explosions, and fires.

Geologically, the potential disasters that may occur in the working area of Puskesmas $\mathrm{X}$ and $\mathrm{Y}$ are earthquakes and landslides. The earthquake risk index score in the South Jakarta area is moderate [23]. According to Center for Volcanology and Geological Disaster Mitigation, the potential for land movement in the sub-districts of the two public health centers is medium. This means that landslides can occur in this area if the rainfall is above normal, especially in areas near the cliff roads or river valleys [24].

Hydrometeorological disasters that may occur in Puskesmas $\mathrm{X}$ and Puskesmas Y are tornadoes and floods. Most areas of DKI Jakarta are at risk of tornado due to climate change, increased temperature, rainfall, and area topography [14]. In Puskesmas $\mathrm{X}$ and $\mathrm{Y}$ areas, there are usually strong winds accompanied by heavy rain, but no tornado has occurred. Based on Indonesia's disaster risk index, the risk level for flooding in South Jakarta is moderate [23]. In the past, floods in Puskesmas X and Y work areas usually occurred when the rainfall was high and water from embankments, rivers, or streams overflowed.

Puskesmas $\mathrm{X}$ and Puskesmas $\mathrm{Y}$ are at risk of experiencing danger due to population concentration because their locations are close to population concentrations. During normal times, the number of people seeking treatment in Puskesmas $\mathrm{X}$ is around 300-350 patients per day and, in Puskesmas Y, it is around $800-850$ patients per day. The high concentration of the population creates a possibility for the collapse of the health system due to the increased demand for mass casualties [20]. 
Social conflicts often occur in Jakarta. The main causes of conflict are low education, high unemployment rate, poverty, low education, and a crowded and slum environment. Riots can also occur because of the diversity of religions, races, ethnicities, customs, and languages [25, 26].

The potential environmental health disasters in Puskesmas $\mathrm{X}$ and Puskesmas $\mathrm{Y}$ include epidemics, water contamination, poisoning, and animal attacks. Epidemic/ outbreak/pandemic cases faced by Puskesmas X and Y in the past consisted of diarrhea, avian flu, dengue fever, diphtheria, measles, and COVID-19. Based on the INARISK application, the South Jakarta area is included in the high hazard class for the COVID-19 disaster. As of July 28, 2020, there are 207 confirmed cases of COVID-19 in the Puskesmas X sub-district area and 250 confirmed cases in the Puskesmas Y sub-district area [6]. Water pollution incidents are still experienced by Puskesmas X and Y because there are elements in the water of the two public health centers that had a concentration that was higher that the thresholds in the applicable standard for clean water quality, i.e. the standard threshold for $E$. coli and manganese (Puskesmas X) and nitrates (Puskesmas Y). Water pollution can endanger public health due to pathogens in the form of bacteria and viruses originating from human and animal waste [27]. Both Puskesmas have handled poisoning cases. A poisoning incident occurred four years ago and Puskesmas Y had to treat 11 residents who were poisoned by drinking water refills. Puskesmas $\mathrm{X}$ also handled 4 cases of poisoning caused by food in 2018. In terms of animal attacks, Puskesmas Y still has problems with rats after previously having problems with cockroaches.

In terms of chemical and technological disasters, Puskesmas $\mathrm{X}$ and $\mathrm{Y}$ have the potential to experience explosions and fires. Explosion might happen because the storage of medical gas in the two public health centers does not meet the standard in the Regulation of the Minister of Health of the Republic Indonesia number 4 of 2016 that requires medical gases to be kept in a dedicated room. It is also required that full and empty medical gas cylinders should be kept separately and that safety ropes should be used to secure medical gas cylinders. In addition, both public health centers are at risk of experiencing fire due to the electrical system. Puskesmas $\mathrm{X}$ has experienced a fire in the medicine storage room due to a short circuit of the air conditioner wiring. Puskesmas $\mathrm{Y}$ has also experienced an electric short circuit which caused sparks in the counter area.

\subsection{Structural safety in public health centers}

The structural safety scores of Puskesmas X and Y indicate that the buildings area adequate and there is a low risk that these elements would fail in the event of a disaster. The structural safety score for the PHC (Primary Healthcare Center) is also high, i.e. 0.95 from 1 , which is classified as "a" [28]. Since they were built, the Puskesmas X and Y buildings have never experienced damage or failure in the structure of the buildings due to natural disasters. When referring to the Regulation of the Minister of Public Works of the Republic Indonesia number 29/PRT/ M/2006, the two public health centers are found to have implemented building safety standards, although not entirely, because the buildings of Puskemas $\mathrm{X}$ and Puskesmas $\mathrm{Y}$ are still attached to the buildings next to them. The buildings of Puskesmas $\mathrm{X}$ and Puskesmas $\mathrm{Y}$ may become vulnerable to earthquakes if the they change the main structures, which then result in excessive building loads [29] Both public health buildings have only undergone minor renovations and never have renovations that disturb the main construction. The building conditions of Puskesmas $\mathrm{X}$ and $\mathrm{Y}$ are arguably good, no damage or cracks were observed in columns, beams, beam joints, or loadbearing walls due to weathering and wear. Construction materials for Puskesmas X and Puskesmas Y, which comprise of concretes, are also in good condition and no cracks are found in the concretes.

The proximity of the Puskesmas building to the surrounding buildings needs to be taken into account. The recommended distance between buildings to prevent fire threats is more than 15 meters [20]. However, the two community health centers are attached to the surrounding buildings, creating a risk of fire or impacts during an earthquake [30]. Puskesmas X and Puskesmas Y buildings were built using the guideline for the structure and construction of concrete buildings. However, the structural guideline used was the one applied at the time the buildings were built, not the current one. The best form of building plans to withstand earthquakes is the simple and symmetrical shapes with regular building configurations [29]. This is consistent with the form of the two public health center buildings because the buildings were symmetrical and the columns and beams are in the same size and positioned uniformly in each floor.

\subsubsection{Nonstructural safety of public health centers}

The nonstructural safety ratings obtained by Puskesmas $\mathrm{X}$ and Puskesmas $\mathrm{Y}$ were moderate, indicating that the public health centers still carry risks in dealing with disasters. Detailed discussion on this nonstructural safety is as follows.

\subsubsection{Critical systems}

Puskesmas X has an alternative source of electricity that comes from premium electricity and can operate for more than 3 days. Puskesmas $\mathrm{Y}$ uses a generator that can provide electricity for 2 days as the alternative source for electricity. The generator owned by a public health center should be at least sufficient to meet electricity needs for 3 days because if incidents happen, such as during the greater Jakarta flood in 2020, a power outage might occur for up to 3 days [31].

Most of the electrical wiring at Puskesmas $\mathrm{X}$ is in good condition. However, there are still some cables that are not protected and arranged neatly. The electrical wiring of Puskesmas $\mathrm{Y}$ is damaged, brittle, and some cables are exposed. Many cables in Puskesmas Y do not have cable protectors and they are not neatly arranged. There are also some power outlets in Puskesmas Y that are connected to cable extensions. Open electrical parts, poor cable protection, overloading electrical installations, and damage to electrical equipment can cause fires [32]. Preventive monitoring and maintenance are important so that organizations can be aware of the situation early or they will be aware of the presence of poor bad electrical equipment [33]. Both public health centers have SOPs and monitoring records, but Puskesmas Y does not apply them routinely.

Communication equipment must be in good condition, protected (using pipes), and anchored to the buildings [18] Communication equipment owned by Puskesmas $\mathrm{X}$ and Puskesmas Y are telephones, cellphones, internet, loudspeakers, and between room communication devices. Puskesmas $\mathrm{Y}$ also has walkie talkies. The condition of the communication cables at Puskesmas $\mathrm{X}$ and Puskesmas $\mathrm{Y}$ is quite good. However, there are still some messy communication cables without cable clamps and without 
protection pipe. Puskesmas X and Puskesmas Y do not have SOPs or records for routine inspection of communication systems. The maintenance of the communication system in the two public health centers will only be performed if there is a damage to the system.

In PAHO (2015), it is recommended that the public health centers have sufficient water reserves in a water tank that is able to hold water supply for at least 72 hours or 3 days. However, the water tanks owned by Puskesmas $\mathrm{X}$ and Puskesmas Y are only able to hold water supply for one day. The components of the water distribution system in Puskesmas $\mathrm{X}$ and Puskesmas $\mathrm{Y}$ are in good condition. Water pumps, pipes, pipe fittings, and automatic machines are in good working order. However, there is a little bit of corrosion in the water tank of Puskesmas X. If the water pump is broken, Puskesmas $\mathrm{X}$ can still have water from the neighboring school that can meet $50 \%$ of the water needs. Meanwhile, Puskesmas Y does not have any back up water source.

When a disaster occurs, access to and availability of fuel is very limited [34]. Therefore, the fuel reserve in public health centers should always be maintained to be sufficient for three days. However, the generator fuel reserve in Puskesmas $\mathrm{X}$ is only sufficient one day, while Puskesmas $\mathrm{Y}$ has a fuel reserve for two days. It is estimated that medical gas reserves at Puskesmas X and Puskesmas Y are sufficient for less than 3 days. The storage of medical gasses in both public health centers does not meet the standards in the Regulation of the Minister of Health of the Republic Indonesia number 4 of 2016 because they are not stored in a dedicated room and are not anchored to a wall.

The wastewater disposal system at Puskesmas $\mathrm{X}$ and Puskemas $\mathrm{Y}$ has included a wastewater treatment plant (WWTP) system. The WWTP systems in both public health centers are in good condition. The quality of wastewater at Puskesmas $\mathrm{X}$ and Puskesmas $\mathrm{Y}$ is routinely checked, but the results are still above the required wastewater quality standards for coliform and ammonia parameters (Puskesmas $\mathrm{X})$ and ammonia parameters (Puskesmas Y). The solid waste Puskesmas $\mathrm{X}$ and $\mathrm{Y}$ is separated into domestic solid waste and hazardous waste. The management of domestic waste and hazardous waste in Puskesmas X and Puskesmas $\mathrm{Y}$ was performed according to the Regulation of the Minsiter of Health of the Republic Indonesia Number 7 of 2019 that includes requirements for waste separation, adequate container capacity, plastic bag use according to the type of waste, the hazardous temporary waste collection point is sheltered from rain and sunlight with hazardous symbol attached, and the location of the temporary waste collection point is far from the place for providing essential services.

The roof of Puskesmas X is made of concrete, flat in shape, and some puddles of water are still found on the roof due to the lack of drainage. The roof of Puskesmas Y takes the form of a saddle roof with a slope that is sufficient to drain rainwater.

\subsubsection{Air conditioning system}

The air conditioners in Puskesmas $\mathrm{X}$ are functioning properly. However, there are still air conditioners that do not have brackets and pipes that are not neatly positioned. Some air conditioners in Puskesmas $\mathrm{Y}$ are not functioning properly and there are still pipes that are not neatly positioned.

\subsubsection{Furniture and equipment, office equipment, and storage}

Furniture and other equipment such as TVs, refrigerators, cabinets, and storage racks need to be attached or affixed to the walls to prevent them from falling during a disaster [35]. However, in both public health centers, such equipment is not affixed to the wall.

\subsubsection{Medical and laboratory equipment and supplie}

According to WHO (2004), supplies should be stored in closed cabinets that are affixed to the wall. Medical support equipment also needs to be affixed to prevent interruption of treatment provision during a disaster. However, in both public health centers, medical and laboratory equipment storage cabinets are not affixed to the wall. Medical instrument tables and baby cots also do not have wheel locks and medical support equipment is not tied to the patient's bed.

\subsubsection{Architectural elements}

The public health centers' doors, roof, stairs, walls, and floors are in good condition. There is the potential for trees and electric poles to fall that can obstruct vehicle access when the requirement is that the outside area of a public health center building must be barrier-free so as not to interfere with the function of the public health center [20]. There are also obstacles to movement inside the public health center building, such as the positioning of waiting chairs, tables, filing cabinets This does not comply to the Regulation of the Minister of Public Works of the Republic Indonesia number 26/PRT/ $\mathrm{M} / 2008$ that requires stairs and corridors to be free from obstacles. Fire protection systems that have to be available in public health centers are smoke detectors, alarms, fire extinguishers, hydrants, and sprinklers [20]. However, Puskesmas $\mathrm{Y}$ only has a hydrant and portable fire extinguishers while Puskesmas $\mathrm{X}$ does not yet have sprinklers and the hydrant is out of order.

\subsubsection{Functional aspects of public health centers}

Puskesmas $\mathrm{X}$ already has a team for emergency response, but it is not yet functioning effectively. Meanwhile, Puskesmas $\mathrm{Y}$ is still in the process of establishing such team when the presence of the team is the first step towards developing preparedness measures for public health centers in implementing emergency response and recovery actions [36]. Action cards are the basis of a successful disaster management plan. These cards contain detailed tasks in the context of a disaster and should be given to each public health center staff member [36]. Puskesmas $X$ and Puskesmas $Y$ have not yet prepared and distributed action cards for employees in the public health centers.

Puskesmas $\mathrm{X}$ and Puskesmas $\mathrm{Y}$ do not yet have an emergency response plan, procedures for strengthening Puskesmas essential services, procedures for activation and deactivation the plan, procedures for employee welfare, as well as procedures for space expansion, communication with the public and the media, and employee mobilization. Puskesmas X and Puskesmas $\mathrm{Y}$ have SOPs for admitting and treating patients, triage, and referrals but they have never been tested for a disaster situation. Puskesmas $\mathrm{X}$ has hazard-spesific sub plans for floods, earthquakes, fires, volcanic eruptions, social unrest, terrorism, power outage, tornadoes, and baby kidnappings. Of all those plans, only fire and earthquake plans are already tested. Compared to Puskesmas X, Puskesmas $\mathrm{Y}$ only has a fire plan that is routinely tested every year. Puskesmas $\mathrm{X}$ has made an evacuation plan, which is absence in Puskesmas Y. Puskesmas Y also does not have an emergency warning system for health sector and does not have any alarm. 
The availability of medicines, equipment, and medical supplies is an important aspect of a facility's capacity to cope with the surge of patients during a disaster [28, 37]. Puskesmas $\mathrm{X}$ and $\mathrm{Y}$ have sufficient stocks of medicines and PPE for 3 days. The supplies of sterile equipment at Puskesmas $\mathrm{X}$ are only sufficient for less than 3 days and Puskesmas $\mathrm{Y}$ has supplies of sterile equipment that are sufficient for 3 days. The life support equipment in Puskesmas $\mathrm{X}$ and Puskesmas $\mathrm{Y}$ is only sufficient for daily use. Puskesmas X and Puskesmas $\mathrm{Y}$ routinely hold disaster training such as fire and earthquake training. Not all employees in Puskesmas X and Puskesmas Y have received disaster training every year because it is performed in batches.

During the COVID-19 pandemic disaster, Puskesmas X and Puskesmas Y need to prepare their facilities so that they can provide services during the pandemic. Puskesmas $\mathrm{X}$ and Puskesmas Y have made adjustments to the annual activity planning, by postponing activities or changing methods such as giving health education via zoom. Puskesmas $\mathrm{X}$ and Puskesmas $\mathrm{Y}$ have received an additional duty during the pandemic to monitor cases related to COVID-19 managed by urban village public health centers in their areas, perform close contact tracing, and perform sweeping of people who have just returned from a trip.

Puskesmas X and Puskesmas Y have drawn a COVID-19 distribution map that divides their work areas into red, yellow, and green zones at the neighborhood level. They also map the demographic distribution of the age and sex of COVID-19 positive patients. The work distribution for Puskesmas $\mathrm{X}$ and Puskesmas Y employees has also been reviewed to adjust for employee risks. In Puskesmas X, pregnant employees are not deployed in the frontline and limitations are applied for preelderly employees in doing field works. In Puskesmas Y, employees who are elderly or pregnant can work from home. The reason for this is because older health care workers have a higher health risks that make them vulnerable to being infected with COVID-19 [38]. Puskesmas X and Puskesmas Y have trained their employees on how to use PPE.

Both public health centers have coordinated with the neighborhood leaders (RT and RW), community leaders, urban village government, sub-district government, and other sectors for patient monitoring, reporting, and community education in the form of education sessions or outreach conducted through social media. Direct education sessions are also held in public places.

If a patient found to be COVID-19 positive, the public health center must communicate the risk to the patient, family, and community [39]. Puskesmas X and Puskesmas Y have provided education to patients, families, and communities who live in the surrounding areas of the patient's home regarding the protocol for COVID-19 patients at home, how to care for patients, and how to prevent from getting COVID-19.

In Puskesmas X, examinations for pregnant women, neonatal services, elderly services, labor and delivery services for women not related to COVID-19, immunization, and family planning are still provided in the public health center building. For postnatal care, if there are no complaints, the women can use the telemedicine facility for consultation. Puskesmas Y still allows direct visits for pregnant women services, labor and delivery services for women not related to COVID-19 cases, family planning services, postpartum services, malnutrition services, mandatory immunization services, elderly services, and neonatal services. The two Puskesmas have not started the Posyandu (integrated health post) services yet. Monitoring of children's growth and development in Puskesmas $\mathrm{X}$ and Puskesmas $\mathrm{Y}$ is done online.

Puskesmas $\mathrm{X}$ and $\mathrm{Y}$ provide free COVID-19 rapid tests and swab tests to the public who have been previously screened and are referred to the public health center due to the presence of moderate and severe symptoms. In terms of mental health and psychological support, both public health centers provide counseling services. Mental health support needs to be provided to the health care workers and patients because they are at risk of experiencing mental health problems such as depression, anxiety, anxiety, and other mental problems [40]. Puskesmas $\mathrm{X}$ only has counseling services for health care workers and Puskesmas Y only has counseling services for patients.

The business-as-usual operation of the public health centers has raised concerns over the potential transmission of COVID19. Screening, such as temperature checks in health services, aims to maintain the safety and health of employees and patients [41]. Patients are screened, by checking their temperature and symptoms. In Puskesmas X, patients with symptoms are not allowed to enter, while in Puskesmas Y, symptomatic patients will be directed to a dedicated counter.

Both public health centers have made an SOP for the patient care flow according to the risk of COVID-19 exposure of COVID-19 which contains the sequence of patient care processes. Both public health centers also provide hand washing stations and hand sanitizers; implement social distancing; and require the uses of PPE based on locations, professions, and activities. The procedure for disposing of used PPE in these public health centers comply with the regulations of the Indonesian Ministry of Health of the Republic Indonesia (2020). Both public health centers also routinely disinfect surface areas, such as desks, door handles, handrails, etc.

\section{LIMITATIONS OF THE STUDY}

During the interview, the source needs to confirm to several other public health center employees to get the answer. Therefore, it is better to do interview for each module in the form of FGD so that the answers from the participants can complement each other. None of the public health centers' employees have civil engineering or architecture background to be able to become the source of information for structural safety. Hence, questions in interviews need to be made simpler to make it comprehensible for the informants. One of the public health centers has not had an emergency response team that it is difficult to determine the information source for functional aspects.

\section{CONCLUSIONS}

Potential disasters that might occur in both public health centers and their working areas are earthquakes, landslides, tornadoes, floods, river flooding, population concentration, social conflicts, epidemics, poisoning, water contamination, explosions, and fires. The results of this study show that the disaster preparedness scores for Puskesmas X and Puskesmas $\mathrm{Y}$ are 0.65 and 0.6 , respectively. Both scores were in classification $\mathrm{B}$, meaning that interventions need to be done in the near future because the public health centers are still facing risks to survive a disaster in the aspects of safety and 
management. Based on these results, the following recommendations are made for the two public health centers:

- Efforts should be made to identify potential disasters in the public health centers to be able to compile and complete the sub-specific disaster plans based on the identified disasters.

- Preparedness in the structural aspects and architectural elements of the public health centers should be improved by regular monitoring of the building and architectural elements as a preventive measure.

- Preparedness of the non-structural aspect of the public health centers in facing disasters should be improved by maintaining a consistent schedule for monitoring and preventive maintenance of the critical systems of the public health centers to maintain a good level of safety, providing a dedicated place for the storage of medical gases and increasing the protection of medical and laboratory equipment by replacing wheeled equipment that does not have wheel locks with the ones that have wheel locks and by tying the equipment to the bed.

- Public health centers should improve their services so that they are ready to face the COVID-19 pandemic by referring to the guideline issued by the ministry of health, i.e. Technical Guideline for Public Health Center Services during COVID-19 Pandemic.

\section{ACKNOWLEDGMENT}

This study was supported by grants from Research and Community Engagement Directorate (DRPM) Universitas Indonesia No. NKB-0592/UN2.R3.1/HKP.05.00/2019.

\section{REFERENCES}

[1] Sunarjo, Gunawan, M.T., Pribadi, S. (2012). Gempa Bumi, 2nd ed. Jakarta: BMKG.

[2] BNPB. (2017). Potensi dan Ancaman Bencana. [Online]. Available:https://www.bnpb.go.id/potensi-ancamanbencana, accessed on 8 July 2020.

[3] Kementerian Energi dan Sumber Daya Mineral. (2018). Miliki 127 Gunung Api Aktif Jadikan Indonesia 'Laboratorium' Gunung Api Dunia.[Online]. Available:https://www.esdm.go.id/id/mediacenter/arsip-berita/miliki-127-gunung-api-aktif-jadikanindonesia-laboratorium-gunung-api-dunia, accessed on 8 July 2020.

[4] BNPB. (2014). Rencana Nasional Penanggulangan Bencana2015-2019.[Online].

Available:https://bnpb.go.id/documents/buku-renaspb.pdf, accessed on 12 July 2020.

[5] BNPB. (2020). Data Informasi Bencana Indonesia. [Online]. Available: https://dibi.bnpb.go.id, accessed on 12 July 2020.

[6] Pemerintah Provinsi DKI Jakarta. (2020). Data Pemantauan COVID-19 DKI Jakarta. [Online]. Available:https://corona.jakarta.go.id/id/datapemantauan, accessed on 28 July 2020.

[7] Shoaf, K.I., Rottman, S.J. (2000). Public Health Impact of Disasters. [Online]. Available: https://www.preventionweb.net/files/2026_VL206801.p df, accessed 28 July 2020.

[8] Maryanti, S., Saputra, A. (2019). Analisis Kerusakan
Bangunan Fasilitas Sosial akibat Gempabumi Tahun 2018 di Kota Palu Provinsi Sulawesi Tengah. [Online]. Available:

https://publikasiilmiah.ums.ac.id/bitstream/handle/1161 7/11625/148_Kom1_SNGUMS2019_Setty.pdf?sequenc e=1\&isAllowed=y, accessed on 30 July 2020.

[9] Sindo News. (2020). Kemenkes: 83.9\% Pelayanan Kesehatan Terdampak Akibat Corona. [Online]. Available:

https://nasional.sindonews.com/read/62388/15/kemenke s-839-pelayanan-kesehatan-terdampak-akibat-corona1591599973, accessed on 30 July 2020.

[10] Mulyasari, F., Inoue, S., Prashar, S., Isayama, K., Basu, M., Srivastava, N., Shaw, R. (2013). Disaster preparedness: Looking through the Lens of Hospitals in Japan. International Journal of Disaster Risk Science, 4(2): 89-100. https://doi.org/10.1007/s13753-013-00101

[11] Sunindijo, R.Y., Lestari, F., Wijaya, O. (2019). Hospital safety index: Assessing the readiness and resiliency of hospitals in Indonesia. Facilities, 38(1/2): 39-51. https://doi.org/10.1108/F-12-2018-0149

[12] Widayatun, Fatoni, Z. (2013). Permasalahan kesehatan dalam kondisi bencana: Peran petugas kesehatan dan partisipasi masyarakat. J. Kependud. Indones., 8(1): 3752. https://doi.org/10.14203/jki.v8i1.21

[13] Oktari, R.S., Kurniawan, H. (2016). Framework ketahanan puskesmas dalam menghadapi bencana. J. Kedokt. Syiah Kuala, 16(1).

[14] BPBD. (2013). Rencana Penanggulangan Bencana Provinsi DKI Jakarta Tahun 2013-2017. [Online]. Available: https://bpbd.jakarta.go.id/wpcontent/uploads/2020/10/Renkon_2016-1.pdf, accessed 30 July 2020.

[15] Rismadianti, A.S. (2019). Hubungan Pengetahuan Dengan Sikap Tenaga Kesehatan Dalam Tanggap Darurat Bencana Banjir di Puskesmas Bidara Cina Jakarta Timur Tahun 2019, UPNVJ.

[16] Kompas. (2020). 5 Pegawai Terpapar Covid-19, Layanan Puskesmas Kecamatan Kebon Jeruk Dialihkan. [Online]. Available:

https://megapolitan.kompas.com/read/2020/07/24/1815 0101/5-pegawai-terpapar-covid-19-layanan-puskesmaskecamatan-kebon-jeruk, accessed on 31 July 2020.

[17] Warta Kota. (2020). Layanan Puskesmas Cempaka Putih Dialihkan Sementara Akibat 3 Nakes Terkonfirmasi Positif Covid-19. [Online]. Available: https://wartakota.tribunnews.com/2020/07/11/layananpuskesmas-cempaka-putih-dialihkan-sementara-akibat3-nakes-terkonfirmasi-positif-covid-19, accessed on 31 July 2020

[18] WHO. (2015). Hospital Safety Index: Guide for Evaluators, 2nd edition.

[19] PAHO and WHO. (2017). Smart Hospitals Toolkit. Washington, D.C.

[20] PAHO. (2015). Hospital Safety Index: Medium and Small Hospitals Safety Index, 4th ed. Washington, D.C: Pan American Health Organization.

[21] FEMA. (2020). Seismic Non-Structural Module. [Online].Available: https://emilms.fema.gov/IS0277/modules/Mod7sns/BCA0700summary.htm, accessed on 03 August 2020.

[22] Kementerian Kesehatan Republik Indonesia. (2020). 
Petunjuk Teknis Pelayanan Puskesmas Pada Masa Pandemi Covid-19, Jakarta.

[23] BNPB. (2018). Indeks Risiko Bencana Indonesia Tahun 2018. Badan Nasional Penanggulangan Bencana. Jakarta.

[24] PVMBG. (2020). Wilayah Potensi Gerakan Tanah di Provinsi DKI Jakarta Bulan Juni 2020. [Online]. Available:https://vsi.esdm.go.id/index.php/gerakantanah/peringatan-dini-gerakan-tanah/3093-juni-2020, accessed on 12 July 2020.

[25] Titulanita, F., Sumardiati, S., Endang, R. (2015). Kerusuhan Pasar Glodok: Studi Kasus Etnis Tionghoa di Kelurahan Glodok Kecamatan Taman Sari Jakarta Barat. Jakarta

[26] Umar, M. (2014). Peta Konflik Sosial di DKI Jakarta. Institute for Social Empowerment and Democracy. Jakarta.

[27] Denchak, M. (2018). Water Pollution Facts, Types, Causes and Effects of Water Pollution. [Online]. Available: https://www.nrdc.org/stories/water-pollutioneverything-you-need-know, accessed on 30 July 2020.

[28] Lapčević, Z., Mandić-Rajčević, S., Lepić, M., Jovanović, M. (2019). Evaluating a primary healthcare centre's preparedness for disasters using the hospital safety index: Lessons learned from the 2014 floods in Obrenovac, Serbia. Int. J. Disaster Risk Reduct., 34: 436-442. https://doi.org/10.1016/j.ijdrr.2018.12.014

[29] Zulfiar, M.H., Tamin, R.Z., Pribadi, K.S., Imran, I. (2014). Identifikasi Faktor Dominan Penyebab Kerentanan Bangunan Di Daerah Rawan Gempa, Provinsi Sumatera Barat. J. Ilm. Semesta Tek., 17(2): 116-125. http://http://journal.umy.ac.id/index.php/st

[30] Isteita, M., Porter, K. (2017). Safe Distance Between Adjacent Buildings To Avoid Pounding in Earthquakes. $16^{\text {th }}$ World Conference on Earthquake, 16WCEE 2017. Santiago, Chile.

[31] CNBC Indonesia. (2020). Pasca Banjir Listrik Masih Padam, Ini Penjelasan PLN. [Online]. Available: https://www.cnbcindonesia.com/news/20200103103551 -8-127346/pasca-banjir-listrik-masih-padam-inipenjelasan-pln, accessed on 01 August 2020.

[32] Badan Standardisasi Nasional. (2018). Pemberlakuan Wajib SNI Peralatan Listrik, Lindungi Konsumen. [Online]. Available: https://bsn.go.id/main/berita/detail/9849/pemberlakuan- wajib-sni-peralatan-listrik-lindungi-konsumen, accessed on 12 August 2020.

[33] Malhotra, R., Alzahawi, T., McLeod, E. (2019). Management and maintenance of electrical equipment in industrial facilities. 2019 IEEE/IAS 55th Industrial and Commercial Power Systems Technical Conference (I\&CPS), Calgary, AB, Canada, pp. 1-6. https://doi.org/10.1109/ICPS.2019.8733336

[34] Yuwanto. (2018). Pembenahan BTS di Pelosok Bencana, Pemulihan Ekonomi Rakyat. Republika Online. Available:

https://www.republika.co.id/berita/pkh3tv438/pembena han-bts-di-pelosok-bencana-pemulihan-ekonomi-rakyat, accessed, 15 August 2020.

[35] WHO. (2004). Guidelines on Non-Structural Safety in Health Facilitie. [Online]. Available: https://apps.who.int/iris/bitstream/handle/10665/205185 /B0610.pdf?sequence $=1 \&$ isAllowed $=y$, accessed 15 August 2020.

[36] Government of India. (2002). Guidelines for Hospital Emergency Preparedness Planning. New Delhi.

[37] Djalali, A., Ardalan, A., Ohlen, G., Ingrassia, P., Corte, F., Castren, M., Kurland, L. (2014). Nonstructural safety of hospitals for disasters: A comparison between two capital cities. Disaster Medicine and Public Health Preparedness, $\quad 8(2)$ : $179-184$. https://doi.org/10.1017/dmp.2014.21

[38] Mhango, M., Dzobo, M., Chitungo, I., Dzinamarira, T. (2020). Dzinamarira, COVID-19 risk factors among health workers: A rapid review. Safety and Health at Work, 11(3): 262-265. https://doi.org/10.1016/j.shaw.2020.06.001

[39] Direktorat Jenderal Pencegahan dan Pengendalian Penyakit. (2020). Pedoman Kesiapsiagaan Menghadapi CoronaVirus Disease (COVID-19). Jakarta.

[40] Grover. S., Dua, D., Sahoo, S., Mehra, A., Nehra, R., Chakrabarti, S. (2020). Why all COVID-19 hospitals should have mental health professionals: The importance of mental health in a worldwide crisis! Asian J Psychiatr. https://doi.org/10.1016/j.ajp.2020.102147

[41] Collins, S. (2020). Some Hospitals Screening Everyone for COVID-19 Symptoms. [Online]. Available: https://www.sunjournal.com/2020/03/24/somehospitals-begin-screening-everyone-for-covid-19symptoms/, accessed 30 August 2020. 